
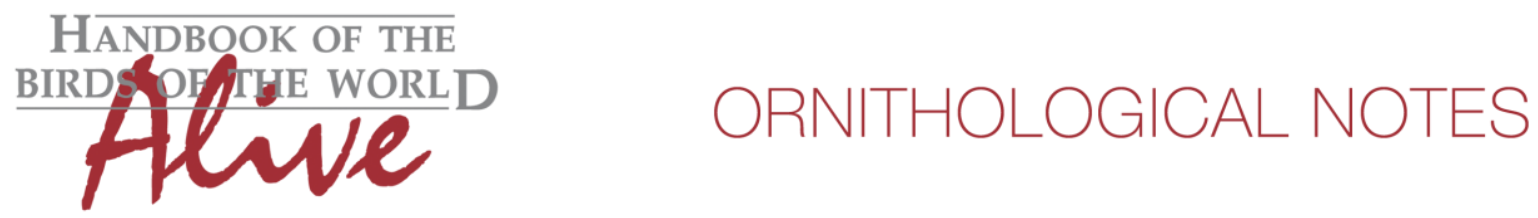

\title{
Notes on the vocalizations of Grey-crowned Flycatcher (Tolmomyias poliocephalus)
}

\section{Peter Boesman}

In the following we briefly analyze and compare voice of the three different races of Greycrowned Flycatcher (Tolmomyias poliocephalus). We also try to quantify the extent of any vocal differences using the criteria proposed by Tobias et al. (2010), as a support for taxonomic review. We have made use of sound recordings available on-line from Xeno Canto (XC).

Most common vocalizations are either a repeated single overslurred note, or a repeated series of 4-5 notes which gradually rise in pitch. The latter can be considered song, and is given both at dawn and during the day.

In the following, we compare this 4-5 note 'song' of the 3 races.

klagesi (C \& E Venezuela (N Amazonas, Bolívar, Delta Amacuro))

A series of 4 notes, which consistently rise in pitch and become louder. Note shape changes from rather flat to irregularly overslurred. All recordings very similar:

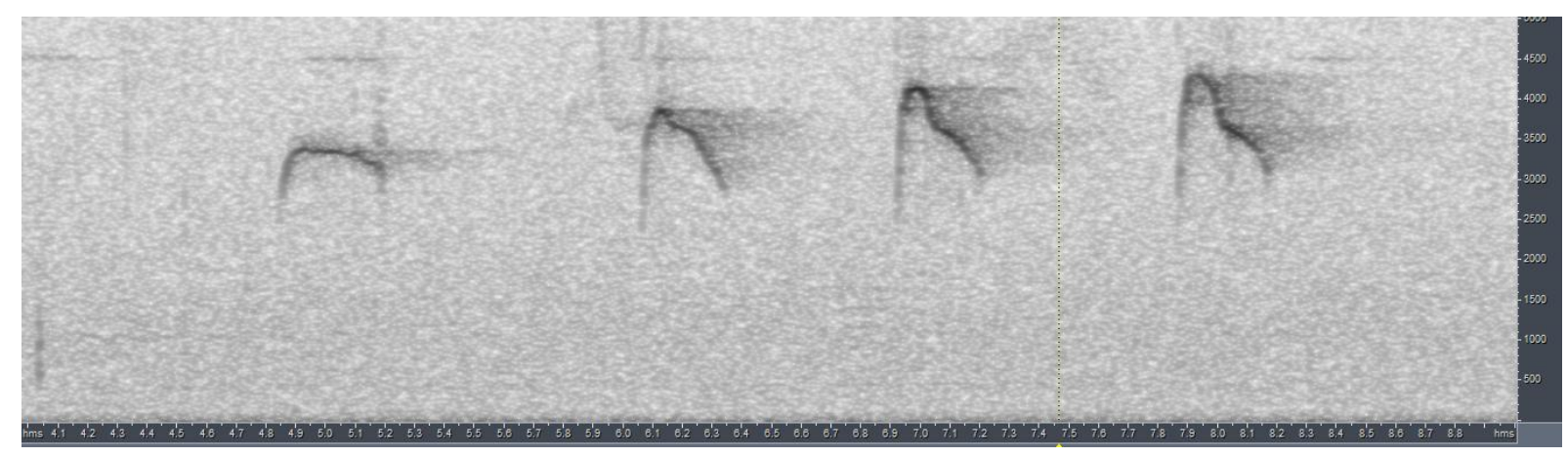

Measurements:

total length

start max. freq.

end max. freq.

freq. rise

freq. range

max note length 2.97-3.38s

$3100-3700 \mathrm{~Hz}$

$4300-4560 \mathrm{~Hz}$

$860-1350 \mathrm{~Hz}$

$1600-2200 \mathrm{~Hz}$

$0.32-0.38 \mathrm{~s}$ 

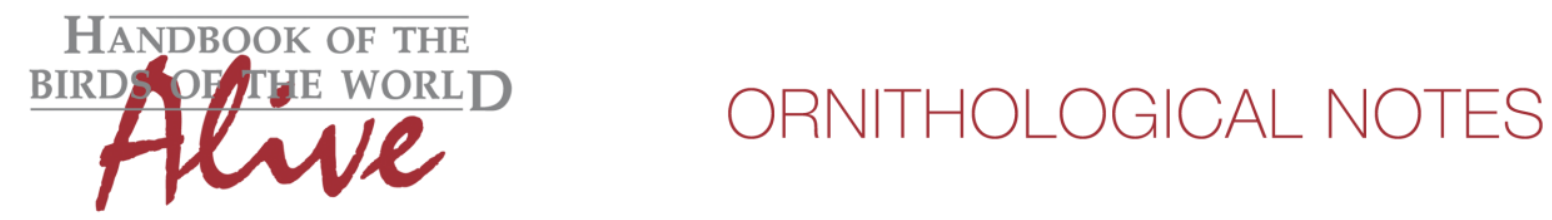

sclateri (the Guianas through E Amazonian Brazil to N \& C Bolivia; also isolated population in coastal E Brazil (Pernambuco S to Espírito Santo))

A series of 4 notes, without clear pattern. Sometimes close to previous group, sometimes all rather flat whistles. In general, this taxon seems to utter less frequently this note series (based on available recordings):

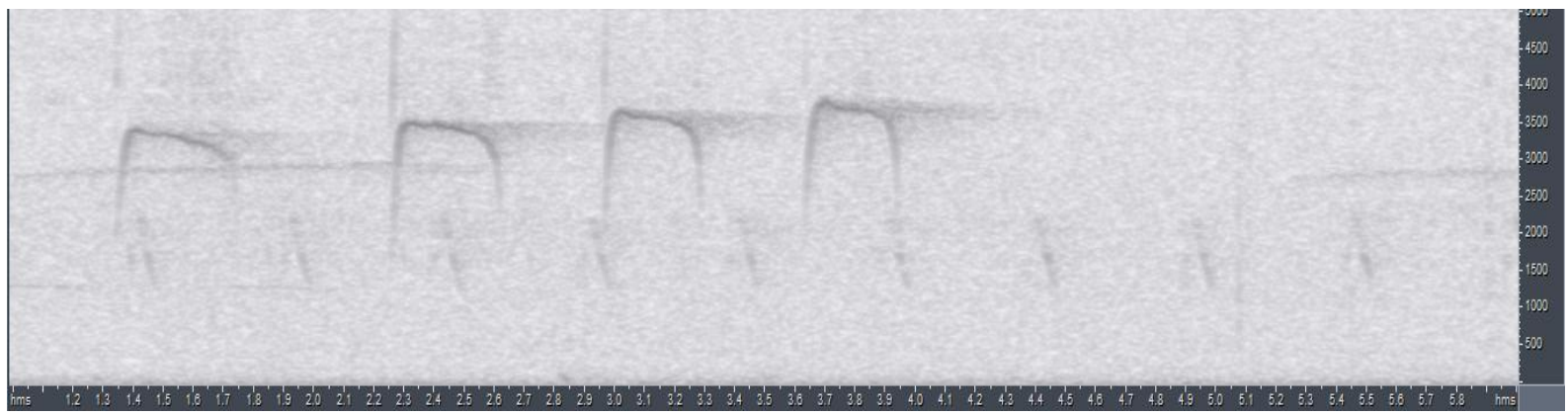

Measurements:

total length

2.61-3.12s

start max. freq.

$3280-3400 \mathrm{~Hz}$

end max. freq.

$3700-3900 \mathrm{~Hz}$ (up to $4500 \mathrm{~Hz}$ in Suriname)

freq. rise

$420-520 \mathrm{~Hz}$ (up to $1000 \mathrm{~Hz}$ in Suriname)

freq. range

$1200-2000 \mathrm{~Hz}$

max note length

$0.31-0.36 \mathrm{~s}$

poliocephalus (SW Venezuela (S Amazonas), E \& SE Colombia, E Ecuador, E Peru, and W Brazil (W Amazonas E to right bank of lower R Negro and Tefé))

A series of 4-5 whistles, of which typically the last two ones are distinctly bisyllabic (with second syllable usually highest in frequency).

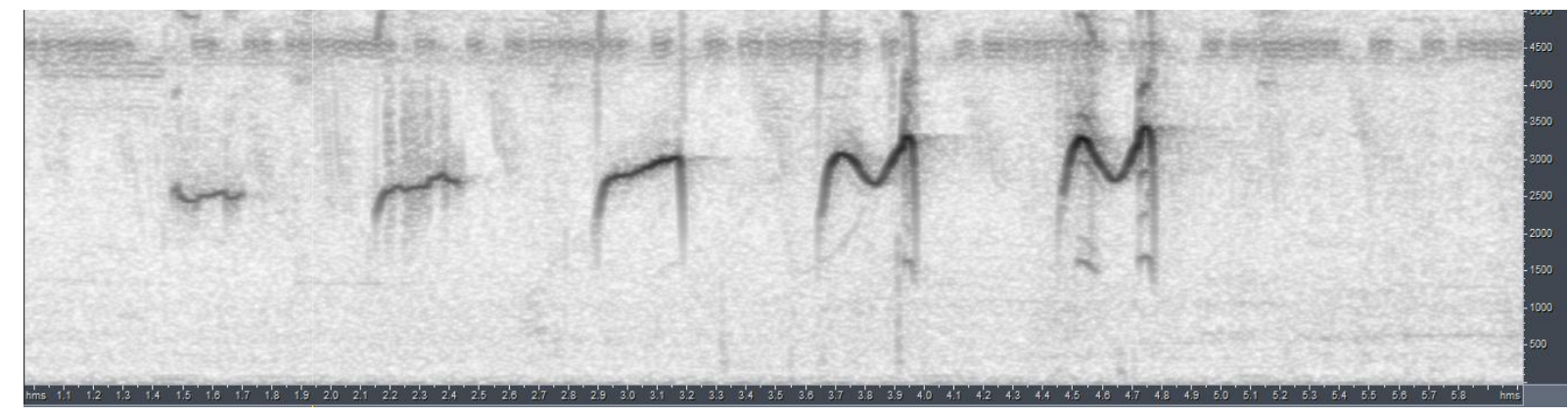

Measurements:

total length

start max. freq.

end max. freq.

freq. rise

freq. range

max note length 3.0-4.5s

$2600-3100 \mathrm{~Hz}$

$3100-3700 \mathrm{~Hz}$

$400-850 \mathrm{~Hz}$

1100-1600hz

$0.36-0.42 \mathrm{~s}$ 

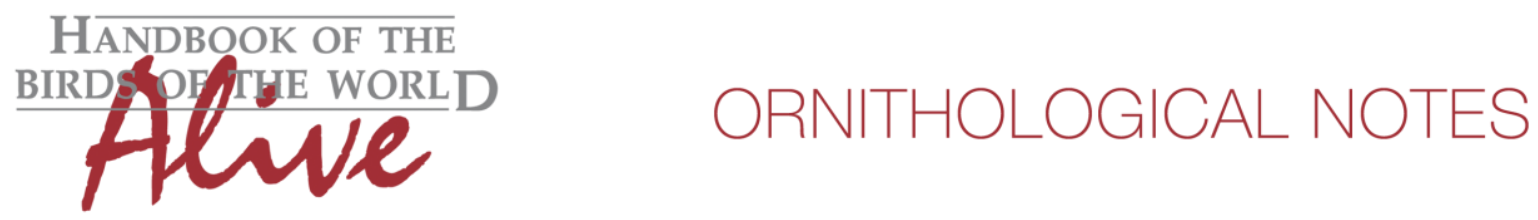

From the above it is clear that song is structurally similar, with slight differences in note shape.

klagesi seems to reach the highest frequencies with the highest rise in frequency between first and last note. A recording from Suriname (XC7616) however is indistinguishable from klagesi. The confusing situation of klagesi vs sclateri thus remains after checking here their voice. We would need more recordings to evaluate if there is another dividing line than the one suggested by the subspecies geographical distribution (Amazon river?), or whether there is rather a clinal variation.

poliocephalus is more easily recognized, because of the bisyllabic last notes. This also leads to slightly higher length of the longest note (score 2). Furthermore, frequencies tend to be lower (score 2). When applying Tobias criteria, this would lead to a total vocal score of about 4.

This note was finalized on 19th August 2015, using sound recordings available on-line at that moment. We would like to thank in particular the many sound recordists who placed their recordings for this species on XC.

\section{References}

Tobias, J.A., Seddon, N., Spottiswoode, C.N., Pilgrim, J.D., Fishpool, L.D.C. \& Collar, N.J. (2010). Quantitative criteria for species delimitation. Ibis 152(4): 724-746.

\section{Recommended citation}

Boesman, P. (2016). Notes on the vocalizations of Grey-crowned Flycatcher (Tolmomyias poliocephalus). HBW Alive Ornithological Note 122. In: Handbook of the Birds of the World Alive. Lynx Edicions, Barcelona. (retrieved from http://www.hbw.com/node/932045 on 4 August 2016). 